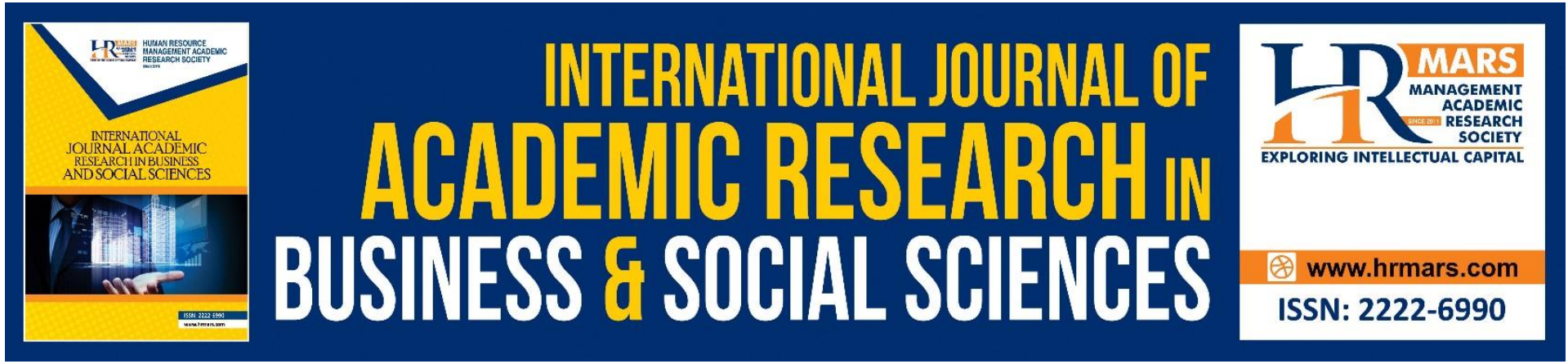

\title{
Preliminary Analysis on The Relationship Between Achievement Goal, Perceived Teacher Instructional Practices and Students' English Achievement
}

Amirah Mohd Juned, Faizah Abd. Majid, Sharifah Muzlia Syed Mustafa, Anuar Sopian, Asma' Fauzi, Aqilah Arshad

To Link this Article: http://dx.doi.org/10.6007/IJARBSS/v11-i7/10538

DOI:10.6007/IJARBSS/v11-i7/10538

Received: 10 May 2021, Revised: 12 June 2021, Accepted: 09 July 2021

Published Online: 22 July 2021

In-Text Citation: (Juned et al., 2021)

To Cite this Article: Juned, A. M., Majid, F. A., Mustafa, S. M. S., Sopian, A., Fauzi, A., \& Arshad, A. (2021). Preliminary Analysis on The Relationship Between Achievement Goal, Perceived Teacher Instructional Practices and Students' English Achievement. International Journal of Academic Research in Business and Social Sciences, 11(7), 840-849.

Copyright: (c) 2021 The Author(s)

Published by Human Resource Management Academic Research Society (www.hrmars.com) This article is published under the Creative Commons Attribution (CC BY 4.0) license. Anyone may reproduce, distribute, translate and create derivative works of this article (for both commercial and non-commercial purposes), subject to full attribution to the original publication and authors. The full terms of this license may be seen at: http://creativecommons.org/licences/by/4.0/legalcode

Vol. 11, No. 7, 2021, Pg. 840 - 849

Full Terms \& Conditions of access and use can be found at http://hrmars.com/index.php/pages/detail/publication-ethics 


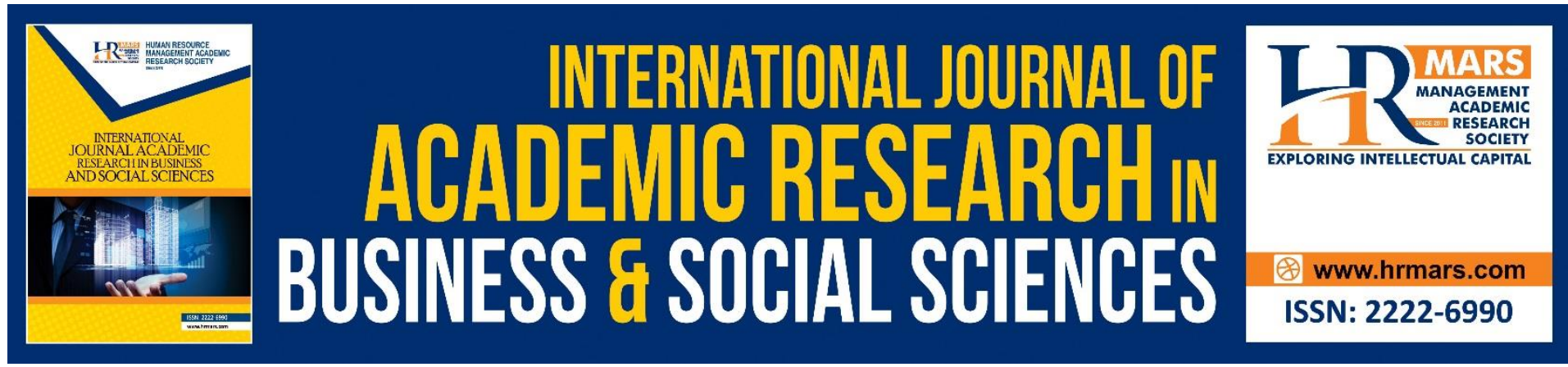

\title{
Preliminary Analysis on The Relationship Between Achievement Goal, Perceived Teacher Instructional Practices and Students' English Achievement
}

\author{
Amirah Mohd Juned ${ }^{1}$, Faizah Abd. Majid², Sharifah Muzlia \\ Syed Mustafa ${ }^{3}$, Anuar Sopian $^{4}$, Asma' Fauzi $^{5}$, Aqilah Arshad $^{6}$ \\ 1,2,3 Faculty of Education, Universiti Teknologi MARA, Malaysia, ${ }^{4,5,6}$ Academy of \\ Language Studies, Universiti Teknologi MARA Melaka, Malaysia \\ Email: amirahjuned@uitm.edu.my
}

\begin{abstract}
This study examines the association between achievement goal, perceived teacher instructional practices and English academic achievement. The study was conducted on the 50 form Four students in a sub-urban school district in Klang valley. The students completed the questionnaire regarding their achievement goal and their perception of English teachers' instructional practices. Based on the correlation analysis, the findings showed that masteryapproach was significantly associated with English achievement. Meanwhile, perceived teachers' instructional practices showed that none of teacher instructional practices associated with English achievement. This has shown that students' motivation in academic achievement play an important role in students' learning.
\end{abstract}

Keywords: Achievement Goals, Academic Achievement, Instructional Practices

\section{Introduction}

English is a fundamental language in Malaysia as it is not only used for communication but also for other purpose. In Malaysia education system, English is a compulsory second language taught in school beginning at Primary One. It is beneficial for the students to comprehend and communicate in English efficiently because it is used as a medium to acquire knowledge and information in a variety of fields such as politics, security, global trade, and education (Ng \& Ng, 2015; Zubairi \& Sarudin, 2009). Based on the Malaysia Blue Print 20132025, the Ministry of Education Malaysia aims to develop students who are proficient in English language so that students are equipped to work in a globalised economy where English language is the international language of communication. However, Malaysia faces a number of challenges as far as the teaching of English is concerned. According to Darus (2013), teachers are facing challenges to find the best approach to teach English. 


\section{Background of Study}

Among the various investigation in search of contributing factors to academic achievement, motivation and teacher instructional practices have been identified as the most influential predictors of students' success or failure in school. Students' academic achievement has often been measured through their performance in examinations and this has become a significant measure of success in the field of education (Muzlia, 2015). Due to the importance of academic achievement to the students', practitioners and researchers continuously identify the factors that could improve students' academic achievement.

Motivation is one of the important factors that could influence students' academic achievement. One of the motivation that has been widely used to study on students' motivation and achievement is achievement goal theory (Midgley, Kaplan, \& Middleton, 2001; Pajares \& Cheong, 2003). Achievement goals have been defined as general reasons that lead students to approach, engage, and respond in different achievement tasks and situations in specific ways (Ames, 1992; Dweck \& Leggett, 1988). This goal helps to understand the students' academic achievement and learning (Ames, 1992; Meece, Anderman, \& Anderman, 2006).

\section{Statement of Problem}

English language is one of the language that has been used widely all over the world. At school teachers play an important role to promote interest in following the lesson in the classroom. Not only teachers that need to promote students' interest in classroom, students also need to arouse themselves to learn the language well by having some motivation within them. For some students, learning English as a second language is one of the most difficult subject they have learnt. Besides that, according to Fitriah \& Noraini (2017), students especially from rural area seem to be unable to perform well in the subject matter. Thang \& Jaafar (2011), they identified that two elements that caused the students not perform well in English subject; attitude and motivation. It was suggested students with low motivation will experience unsuccessful learning compared to students with high motivation. Yunus \& Khairunnisa (2011), has identified that students who have good language proficiency are those who have better motivation in learning. Many research on students' motivation had been conducted by the past researchers. The present study looked at on achievement goal and will identify which achievement goal has significant relationship with English achievement. Additionally, teacher instructional practices were found to have major impact on student learning outcome (Wang, Haertel, \& Walberg, 1993). It has been demonstrated that the quality of instruction is fundamental in learning process. However, researchers agree that there is no well-defined description for the best way of teaching (Bota \& Tulbure, 2015). Hence, the present study explored the role of perceived teacher instructional practices in relation to goal orientation and academic achievement on a sample of secondary school students. The following research questions guided the data collection and analysis:

1) Is there any significant relationship between achievement goals and English achievement?

2) Is there a significant relationship between teachers' instructional practices and English achievement?

\section{Literature Review}

Achievement goals and academic achievement 
Achievement goal theory is one of the most prominent theoretical perspectives on understanding students' achievement motivation (Hulleman et al., 2010; Wirthwein et al., 2013). Initially, there were two types of achievement goals which are; a) mastery goals which focuses on developing students' competency and understanding, and b) performance goals which focuses on demonstrating one competency relative to others (Matos et al., 2017). In explaining about mastery and performance goal, a contrast between approach and avoidance dimensions was added for both goals (Elliot \& Church, 1997; Elliot \& McGregor, 2001).

This distinction was fundamentally based upon whether students want to look competent or avoid looking incompetent at their schoolwork (Harackiewicz, Barron, \& Elliot, 1998). Therefore, the $2 \times 2$ achievement goal framework was developed which postulates four types of goals: (1) mastery-approach goals oriented towards gaining new knowledge, improving and developing knowledge and skills, (2) mastery-avoidance goals referring to avoiding misunderstanding and not mastering task, (3) performance-approach goal oriented towards showing one's competences and outperforming other; and (4) performanceavoidance goals focused on preventing failures. Many studies have suggested that achievement goal theory is employed to predict and understand different students' learning outcomes (Diaconu-Gherasim \& Măirean, 2016).

Teacher instructional practices and academic achievement

Recent discussions on the effectiveness of school inputs in raising students' outcomes with a focus on teacher factors have shown that students with more effective teachers perform better during the achievement test (Zakharov, Carnoy, \& Loyalka, 2014). Studies have revealed that teacher instructional practices have major impact on student learning outcomes (Wang, Haertel, \& Walberg, 1993). Instructional practices comprise of manner, methods or means in which the teachers convey their information, and influence students' behaviour towards understanding and learning (Bota \& Tulbure, 2015). Scholars have distinguished four dimensions of teachers' instructional practices which are the: masteryoriented instruction, performance-oriented instruction, internal differentiation as well as cognitive stimulation and autonomy (Retelsdorf et al., 2010). Baumer et al (2010) claimed that teachers who emphasize on mastering the demands of learning and on individual process could help students learn better thus influencing the students' positive outcomes.

Mastery-oriented instruction is a high quality/adaptive instructional practices where the method emphasised on the students' effort and progress, autonomy support, comprehensive learning, support of student help-seeking and social orientation. As study Butler and Shibaz (2008) found that the mastery-oriented teachers are highly supportive towards students' question and help-seeking. Besides, Retelsdorf et al (2010) revealed that mastery-oriented teachers are oriented to learn and increase their competency. They want to master their knowledge and compare their current performance with their previous achievement. Usually teachers that used mastery-oriented instruction in their teaching feel successful when they have learned something new, something happened in class made them think, overcome difficulties, and they feel like they teach better compared to the past. Teachers who use mastery-oriented instruction will provide students with challenging and stimulating tasks that promote critical and independent thinking.

Meanwhile, teacher who used performance oriented instruction preferabely use their students' performance as a strategy to improve the students' competency in the classroom. In contrast, teachers create a performance goal structure using rote learning, tasks presentation with single correct answer, frequent tests, encourage competition, and 
emphasise social reference norms by grading students mainly relative to one another (Retelsdorf et al., 2010).

Differentiated instruction (DI) is another teacher instructional practices that was being identified for the present study. DI is an approach that enables teachers to plan strategically to meet the needs of every student. According to Levy (2008), differentiated instruction is a set of strategies for the teacher to meet their students' need in learning and will move them forward as far as possible in their educational path. It is a process that will ensure the students' knowledge and understanding match with their readiness level, interest, and preferred mode (Tomlinson, et al., 2003).

Butler, Streblow, and Schiefele (2010), the cognitive stimulation and autonomy instruction is vital in supporting students' comprehensive learning. Cognitive stimulation and autonomy method provides challenging and stimulating task, emphasises critical and independent thinking, and encourages creative ideas from the students (Retelsdorf, Butler, Streblow, \& Schiefele, 2010). Cognitive strategies instruction is an educational approach which emphasises cognitive processes and skills to boost learning. This approach enables all learners to act more strategically, enjoy more self-confidence, and be more flexible and successful in their learning attempts (Shaghagghi, 2003). This instruction is more towards autonomous learning where the teachers will allow the students to lead themselves in their learning. It is important for the students to be an autonomous learner as it could help to take charge of their own learning by utilising a self-learning and reflection process (Chou \& ChanLin, 2015).

\section{Methodology}

\section{Participants and procedure}

This study used quantitative approach and a set of questionnaire was use as the instrument. Thus, the most suitable research design to answer the questions of this study is correlational design. The samples comprised of 50 Form Four students ( 6 male, 44 female) from a school located in a sub-urban city in Selangor.

Based on the quantitative approach, a set of questionnaire was used as the instrument. The respondents were given the set of questionnaire during a regular lesson. The respondents were instructed to answer all items by referring to their teacher's subject (English language) and also their achievement goals. They were required to respond to each item using a 5-point scale ranging from 1 (strongly not true) to 5 (strongly true). The completed questionnaires were collected immediately to ensure full return rate response. It is important to note that the researcher was present during the administration of the questionnaire to provide clarification if needed by the respondents.

\section{Instrument}

The set of questionnaire were translated into Bahasa Melayu in order to help students to understand the items of the questionnaire better. There were two sets of the questionnaire given to the students. The first set of the questionnaire required the students to identify their teacher teaching practices in the classroom and the assessment of instructional practices used. It was adapted from Schiefele, Streblow, \& Retelsdorf, (2013); Kunter et al., (2002); Midgley et al., (2000). The assessment was based on scales from PISA study and the Pattern of Adaptive Learning Scales (PALS; Midgley et al., 2000). There are four constructs of teacher instructional practices, which are mastery-oriented instruction, performance-oriented instruction, differentiated instruction as well as cognitive stimulation and autonomy. 
The second set of the questionnaire required the students to identify their achievement goal in learning. The questionnaire was adapted from Achievement Goal Questionnaire (AGQ Elliot \& McGroger, 2001). The questionnaire measured four types of achievement goals: Mastery-approach, mastery-avoidance, performance-approach and performance-avoidance.

\section{Reliability of items}

Cronbach's Alpha was conducted in order to measure the reliability, or internal consistency of the items in the instrument. This procedure was used to assess the reliability coefficient for a scale. The coefficient alpha assesses consistency in scores among equivalent items. High alpha indicates that the items on a scale are unambiguous and produce reliable responses. By convention, the value of alpha .05 is acceptable while score more than .07 indicate great reliability (White et al., 2012). Reliability statistics output in Table 1 and 2 show the Cronbach's Alpha for achievement goal and perceived teacher instructional practices.

Table 1: Cronbach's Alpha for Achievement Goal

\begin{tabular}{ccc}
\hline Construct & Number of items & Cronbach's Alpha \\
\hline Performance-Approach & 6 & .859 \\
Performance-Avoidance & 6 & .723 \\
Masterty-Approach & 6 & .660 \\
Mastery-Avoidance & 5 & .796 \\
\hline
\end{tabular}

Table 2: Cronbach's Alpha for Perceived Teacher Instructional Practices

\begin{tabular}{ccc}
\hline Construct & Number of items & Cronbach's Alpha \\
\hline Mastery-Oriented & 6 & .702 \\
Performance-Oriented & 6 & .766 \\
Differentiated Instruction & 4 & .692 \\
Cognitive Stimulation \& & 4 & .859 \\
Autonomy & & \\
\hline
\end{tabular}

As signified in the tables, all constructs have secured Cronbach's Alpha values exceeding the minimum value for acceptance. Hence, the data analysis was carried on.

\section{Findings}

Descriptive analysis

Table 3: Descriptive analysis for English grade

\begin{tabular}{ccc}
\hline & English Grade & \\
\hline English Grade & Frequency & Percent \\
\hline Excellent & 10 & 20.0 \\
Medium & 34 & 68.0 \\
Poor & 6 & 12.0 \\
Total & 50 & 100.0 \\
\hline
\end{tabular}

Table 3 shows the descriptive statistic for English grade from mid-term examination results. It indicates that most of the students are medium (60\%). About (20\%) of the students are excellent and only (12\%) of them are poor. The sample of the study were from first and middle class, hence the result obtained are varied which depend on their class level. 


\section{Correlation Analysis}

Table 4: Correlation for achievement goals and English achievement

\begin{tabular}{|c|c|c|c|c|c|c|}
\hline & & English Score & 1 & 2 & 3 & 4 \\
\hline English Score & & 1 & & & & \\
\hline \multirow{3}{*}{$\begin{array}{l}\text { 1. Performance } \\
\text { Approach }\end{array}$} & Pearson & -.163 & 1 & & & \\
\hline & Correlation & .259 & & & & \\
\hline & Sig. (2-tailed) & & & & & \\
\hline \multirow{3}{*}{ 2. Mastery Approach } & Pearson & $-.337^{*}$ & & 1 & & \\
\hline & Correlation & $\cdot .017$ & & & & \\
\hline & Sig. (2-tailed) & & & & & \\
\hline \multirow{3}{*}{ 3. Mastery Avoidance } & Pearson & .274 & & & 1 & \\
\hline & Correlation & .054 & & & & \\
\hline & Sig. (2-tailed) & & & & & \\
\hline \multirow{3}{*}{$\begin{array}{l}\text { 4. Performance } \\
\text { Avoidance }\end{array}$} & Pearson & -.222 & & & & 1 \\
\hline & Correlation & .122 & & & & \\
\hline & Sig. (2-tailed) & & & & & \\
\hline
\end{tabular}

*. Correlation is significant at the 0.05 level (2-tailed).

**. Correlation is significant at the 0.01 level (2-tailed).

The relationship between achievement goal and English achievement was investigated using Pearson product-moment correlation coefficient. Table 4 shows that there is no correlation and significant relationship between performance approach $(r=-.163$, $p>0.05)$, mastery avoidance $\quad(r=.274, p>0.05)$ and performance avoidance $(r=-.222$, $p>0.05)$. However, there is medium, negative correlation and significant relationship between mastery approach $(r=-.337, p<0.05)$.

Table 5: Correlation for perceived teacher instructional practices and English achievement

\begin{tabular}{|c|c|c|c|c|c|c|}
\hline & & $\begin{array}{c}\text { English } \\
\text { Score }\end{array}$ & 1 & 2 & 3 & 4 \\
\hline English Score & & 1 & & & & \\
\hline \multirow{2}{*}{ 1.Mastery Oriented } & Pearson Correlation & .103 & 1 & & & \\
\hline & Sig. (2-tailed) & .475 & & & \multirow{7}{*}{1} & \\
\hline \multirow{2}{*}{ 2. Performance Oriented } & Pearson Correlation & .183 & & 1 & & \\
\hline & Sig. (2-tailed) & .204 & & & & \\
\hline \multirow{2}{*}{ 3. Differentiated Instruction } & Pearson Correlation & .062 & & & & \\
\hline & Sig. (2-tailed) & .666 & & & & \\
\hline 4. Cognitive Stimulation \& & Pearson Correlation & -.045 & & & & 1 \\
\hline Autonomy & Sig. (2-tailed) & .754 & & & & \\
\hline
\end{tabular}

**. Correlation is significant at the 0.01 level (2-tailed).

*. Correlation is significant at the 0.05 level (2-tailed).

Table 5 shows the findings on the correlation between perceived teacher instructional practices with English achievement. The findings shows that there is no correlation and between perceived teacher instructional practices and English achievement. Hence, perceived teacher instructional practices did not have significant relationship with English achievement. 


\section{Discussions}

The first objective of the present study is to identify the relationship between achievement goals and English achievement. The study was conducted on Form 4 students from ordinary secondary school in Klang valley. Four achievement goals were identified in order to identify their relationship among the students' English achievement; masteryapproach, mastery-avoidance, performance-approach and performance avoidance. The findings showed that mastery approach has significant relationship with English achievement. Mastery approach refers to students who wanted to acquire new knowledge, improving and developing knowledge and skills. Students who are able to master the subject could perform well in the subject. Students' who always wanted to learn new things will help them to gain more knowledge. Besides that, students who adopted mastery approach in their learning will help them to understand better the subject because they aim to master the subject by understanding the content of the subject as thoroughly as possible. It is important for the students to master the subjects because it will help them to perform well at school. English language has been a global language. It is very important for the students to competent in this language so that they can fit into the real world and fit into group of people that they are planning to communicate with. These results are consistent with previous study by DiaconuGherasim \& Măirean (2016). The study indicated that mastery goal orientations could predict English achievement whereby students who maintain higher level of mastery goals had the largest gain in achievement. Hence, mastering English language at school is needed as this could drive them to be more competent in English.

The second objective of the present study is to identify the relationship between perceived teacher instructional practices and English academic achievement. The findings show that none of perceived teacher instructional practices has significant relationship with English achievement. Teacher instructional practices was rated by the students because students' rating can provide unique insight of classroom processes (Fauth et al., 2014). Students' need to rate their teachers according to four dimensions of teacher instructional practices namely mastery oriented, performance oriented, differentiated instruction and cognitive stimulation \& autonomy. Teacher instructional practices play an important role in the classroom because teacher practices refer to how teachers conducted the teaching and learning activities in the classroom.

\section{Conclusion}

In summary, the present study has examined the association between achievement goals, perceived teacher instructional practices and English achievement. Only one achievement goals was found to be correlated with English achievements namely masteryapproach goal orientations. Meanwhile, based on the students' perception of their teacher instructional practices, it was discovered that none of teacher instructional practices have significant relationship with English achievement.

Achievement goal theory provides a useful explanatory framework that assumes that goals are not just stable personal traits, but rather goals can be shaped by the teacher and learning environment (Schunk et al., 2007). ESL teachers are always looking for ways and measures to improve the teaching and learning of English in schools in order to keep learners interested and motivated to learn English. The findings from the present study could be referred to in determining teaching strategies in boosting their students' achievement goals and academic performance at large. 


\section{Acknowledgement}

Special thanks to Institute of Research Management \& Innovation, IRMI for funding this work through GIP Gran No. 600-IRMI 5/3/GIP.

\section{References}

Ames, C. A. (1994) : Classrooms: Goals, structures, and student motivation Journal of 1994 Educational Psychology, 84, 261-271.

Baumer, J., Kunte, M., Blum, W., Brunner, M., Voss , T., and Jordan, A. (1998). Teachers' Mathematical Knowledge, Cognitive Activation in the Classroom, and Student American Educational Research Journal, 133-180.

Bota, O. A., and Tulbure, C. (2015). Aspects Regarding the Relationship Between Teaching Styles and School Results. Procedia - Social and Behavioral Sciences (pp. $285-290$ ). Elsevier Ltd.

Chou, T.-L., \& ChanLin, L.-J. (2015). Autonomous ESL Learning: "Read \& Reflect In English". Social and Behavioral Sciences , 357-360.

Darus, S. (2013). The Current Situation And Issues of The Teaching of English In Malaysia. Retrieved September 21, 2018, from http://r-cube.ritsumei.ac.jp/

Diaconu-Gherasim, L., and Măirean, C. (2016). Perception of parenting styles and academic achievement: The mediating role of goal orientations. Learning and Individual Differences, 49, 378-385.

Dweck, C. S., and Leggett, E. L. (1988). A social-cognitive approach to motivation and personality. Psychological Review, 95 (2), 256-27

Elliot, A. J., and Church, M. (1997). A Hierarchical Model of Approach and Avoidance Achievement Motivation. Journal of Personality and Social Psychology , 218-232.

Elliot, A. J., and McGroger, H. A. (2001). A $2 \times 2$ achievement goal framework. Journal of Personality and Social Psychology, 501-509.

Fauth, B., Decristan, J., Rieser, S., Klieme, E., \& Büttner, G. (2014). Student ratings of teaching quality in primary school: Dimensions and prediction of student outcomes. Learning and Instruction, 29, 1-9. https://doi.org/10.1016/j.learninstruc.2013.07.001

Fitriah, N. A., \& Noraini, C. Y. (2017). Attitudes and Motivation towards English Language among Secondary School Students in Rural Area. Sci.Int (Lahore), 29(6), 1159-1162.

Harackiewicz, J. M., Barron, K. E., and Elliot, A. J. (1998). Rethinking achievement goals: When are they adaptive for college students and why? Educational Psychologist, 33, 1-21

Hulleman, C. S., Schrager, S. M., Bodmann, S. M., and Harackiewicz, J. M. (2010). A meta analytic review of achievement goal measures: Different labels for the same constructs or different constructs with similar labels? Psychological Bulletin, 136, 422-449.

Keys, T., Conley, A., Duncan, G., and Domina, T. (2012). The role of goal orientations for adolescent mathematics achievement. Contemporary Educational Psychology, 37, 4754

Matos, L., Lens, W., Vansteenkiste, M., and Mouratidis, A. (2017). Optimalmotivation in Peruvian high schools: Should learners pursue and teachers promote mastery goals, performance-approach goals or both? Learning and Individual Differences

Maulana, R., Opdenakker, M.-C., and Bosker, R. (2016). Teachers' instructional behaviors as important predictors of academic motivation: Changes and links across the school year. Learning and Individual Differences, 147-156

Meece, J. L., Anderman, E. M., and Anderman, L. H. (2006). Classroom goal structure, student motivation, and academic achievement. Annual Review of Psychology, 57, 487-503. 
Midgley, Kaplan, and Middleton. (2001). Performance-approach goals: Good for what, for whom, under what circumstances, and at what cost? Journal of Educational Psychology, 103, 77-86.

Ng, C. F., Ng, P. K. (2006). The Motivation of English Language Teachers in a Language and Centre. International Journal of Languages, Literature and Linguistics, 87-92.

Pajares, F., Cheong, Y. F. (2003). Achievement goal orientation in writing: A developmental perspective. International Journal of Educational Research, (39) 437-455

Retelsdorf, J., Butler, R., Streblow, L., and Schiefele, U. (2010). Teachers' goal orientations for teaching: Associations with instructional practices, interest in teaching, and burnout. Learning and Instruction, 30-46.

Schiefele, U., Streblow, L., and Retelsdorf, J. (2013). Dimensions of teacher interest and their relations to occupational well-being and. Journal for Educational Research Online, 7-37.

Senko, C., Hulleman, C., and Harackiewicz, J. (2011). Achievement Goal Theory at the Crossroads: Old. Controversies, Current Challenges, and New Directions. Journal Educational Psychologist , 26-47.

Muzlia, S. (2015). Model of Motivation Forces Influencing Academic Achievement Among Secondary School Students Through The Mediation of Flow. Kuala Lumpur.

Tomlinson, C. A., Brighton, C., Hertberg, H., Callahan, C. M., Moon, T. R., Brimijoin, K., . . . Reynolds, T. (2003). Differentiating Instruction in Response to Student Readiness, Interest, and Learning Profile in Academically Diverse Classrooms: A Review of Literature. Journal for the Education of the Gifted, 119-145.

Thang, S. M., Ting, S. L., \& Jaafar, N. M. (2011). Attitudes and motivation of Malaysian secondary students towards learning english as a second language: A case study. $3 \mathrm{~L}$ : Language, Linguistics, Literature, 17(1), 40-54

Wang, M., Haertel, G., and Walberg, H. (1993). Toward a Knowledge Base for School earning . Review of Educational Research, 249-294.

Wirthwein, L., Sparfeldt, J. R., Pinquart, M., Wegerer, J., and Steinmayr, R. (2013). Achievement goals and academic achievement: A closer look at moderating factors. Educational Research Review, 10, 66-89.

Zakharov , A., Carnoy, M., and Loyalka, P. (2014). Which teaching practices improve student performance on high-stakes exams? Evidence from Russia. International Journal of Educational Development, 13-21.

Zubairi, A., and Hj Sarudin, I. (2009). Motivation To Learn A Foreign Language In Malaysia. GEMA Online Journal of Language Studies, 73-87 